\title{
Insertion of the Superior Head of the Lateral Pterigoid Muscle in the Human Fetuses
}

\author{
Inserción de la Cabeza Superior del Músculo Pterigoideo Lateral en Fetos Humanos \\ "Luiz Altruda Filho \& ${ }^{* *}$ Nilton Alves
}

\begin{abstract}
ALTRUDA FILHO, L. \& ALVES, N. Insertion of the superior head of the lateral pterigoid muscle in the human fetuses. Int. J. Morphol., 24(4):643-649, 2006.

SUMMARY: The lateral pterygoid muscle, more specifically its superior head, as we know, is closely related to the temporomandibular joint (TMJ). Particularly in children, in contrast with what was observed in adults, these joints have been rarely studied, by the anatomic functional aspect, little knowing about its functions in the embryonic and fetal periods. We used, in this work, 12 fetuses ranging in age from 16 to 39 weeks of intrauterine life, where we observed that the superior head of the lateral pterygoid muscle is inserted in the disc and in the articular capsule, in all age groups studied, and also, that the fibers and the thickness of the articular disc is, as well as the articular capsule suffer modifications in accordance with the period of development.
\end{abstract}

KEY WORDS: Temporomandibular joint; Lateral pterygoid muscle; Temporomandibular joint disc.

\section{INTRODUCTION}

Classic authors as Chiarugi (1930), Sarnat (1964), Castro (1975); Sicher \& Du Brull (1977), Gardner et al. (1978), Sarnat \& Laskin (1979), Testut \& Latarjet (1979), Warwick \& Willians (1979), Hollinshead (1980), Tamaki (1981), Woodburne (1984), D’Angelo \& Fattini (1985), O’Rahilly (1985), Figun \& Garino (1989), tell that in adults the superior head of the lateral pterygoid muscle has its insertion in the articular disc and in the capsule of the TMJ.

Beyond the classics, other researchers as Choukas \& Sicher (1960), Troiano (1967), Carlson (1967), Porter (1970), Honee (1972), Gaspard et al. (1973), Landucci \& Ramalho (1974), Frere (1981), Wong et al. (1985), Mérida Velasco et al. (1993), Ogutcen-Toller \& Juniper (1993), Bittar et al. (1994), Heylings et al. (1995), Minarelli \& Liberti (1996), Naidoo \& Juniper (1997), Zhang et al. (1998), Akita et al. (2000), Martins Filho \& Almeida (2002), Wierusz \& Wozniak (2004), mention that the superior head of the lateral pterygoid muscle has its insertion in the disc and in the articular capsule.

However, for Pinkert $(1980,1984)$ there is not an insertion of the lateral pterygoid muscle in the capsule and disc, while for Carpentier et al. (1988) the superior head of the lateral pterygoid muscle is attached to the medial portion of the TMJ disc. Piette (1993) says that the accurate insertion of the superior head of the lateral pterygoid muscle is highly discussed.

Based in such controversies, the aim of this work is to investigate the insertion of the lateral pterygoid muscle, through its superior head, in the capsule and the disc of the TMJ, in fetuses from 16 to 39 weeks of intrauterine life.

\section{MATERIAL AND METHOD}

In this work 12 fetuses ranging in age from 16 to 39 weeks of intrauterine life were studied, being six male and six female, fixed with formaldehyde, belonging to Laboratory of Anatomy of the Institute of Biomedical Sciences of the University of São Paulo (ICB-USP) and of the Laboratory of Anatomy of the College of Medicine of the University of Mogi das Cruzes (FMUMC).

The blocks studied were obtained as follows: First, a horizontal incision along the superior edge of the zygomatic arc was done, followed by a descending daily pre-auricular incision guided by the posterior edge of the jaws branch until its angle stood out. After that, the parotid gland was remo-

\footnotetext{
* Universidade de Santo Amaro, São Paulo - Brasil.

** Universidade Estadual Paulista Júlio de Mesquita Filho , Araraquara - Brasil.
} 
ved and detached the masseter muscle. After the osteotomy of the zygomatic arc, as well as the one of the coronoid process, the temporal muscle was removed, exposing the TMJ and the lateral pterygoid muscle.

By doing this, the blocks with the mandibular fossa, the articular disc, the jaws condyle, the articular capsule and posterior third of the lateral pterygoid muscle were obtained, with both the heads. The blocks of the right side had suffered sagital cuts, and of the left side, transversal cuts, with thickness of $20 \mu \mathrm{m}$, and were colored by the Azo Carmin method for analysis in optic microscopy, so that the two of them, of fetuses with age between 20 and 23 weeks of intrauterine life, were analyzed in electronic microscopy of sweepings Jeol, JSM-P15.

\section{RESULTS}

The histological analysis of the blades that were obtained in the preparations, were distributed in 5 groups according to its predominant morphologic characteristics and age.

Group I. Fetuses with 16 to 19 weeks of intrauterine life. In this phase, muscular fibers proceeding from the superior head of the lateral pterygoid muscle can perfectly be observed by inserting its delicate tendons in the capsule and the anterior and thick portion of the articular disc. The tendons follow the direction of the fibers connective tissue of the disc (Fig. 1).

Group II Fetuses with 20 to 23 weeks of the intrauterine life. In this phase muscular fibers is also noticed coming from the superior head of the lateral pterygoid muscle, inserting themselves in the capsule as in the articular disc (Fig. 2), this fact was proven for the electronic microscopy of sweepings (Fig. 3). The direction of the tendons of these muscular fibers obeys the orientation of the connective heads that constitute the articular disc.

Group III. Fetuses with 24 to 27 weeks of intrauterine life. The tissue connective fibers of the articular disc are a little stretched, different from the sinuous fibers in the two preceding groups. Such fact occurs probably due to the action of the superior head of the lateral pterygoid muscle that if inserted in the anterior edge of the disc, get traction the same to the front during the mandibular movements.

In the articular capsule, the flabby connective tissue standard is kept, the presence of vases and nerves in the thicknest portion is observed. The muscular fibers are clearly inserting themselves or crossing the capsule and attached in the anterior edge of the articular disc (Fig. 4).

Group IV. Fetuses with 28 to 31 and 32 to 35 weeks of intrauterine life. In this group, fibers of the lateral pterygoid muscle are observed inserting themselves in the anterior edge of the articular disc and the tendons of these fibers can be verified penetrating in the connective tissue of the disc and obeying the horizontal direction fibers's of this tissue.

As well as the disc and the condyle fibrocartilage covering, the articular capsule is, also, thicker, fibers of the lateral pterygoid muscle crossing its fibers can be observed (Fig. 5).

Group V. Fetuses with 36 to 39 weeks of intrauterine life. In this phase all the structures of the TMJ are perfectly characterized and developed, that is, the condyle is already in an advanced phase of ossification, its covering fibrocartilage is adhered, without a well characterized zone of transition, the disc and the articular capsule present the same characteristics of the previous group. It must be standed out, however, the presence of muscular fibers of the superior head of the lateral pterygoid muscle inserting themselves in its anterior edges (Fig. 6).

\section{DISCUSSION}

Classic authors as Chiarugi, Sarnat, Castro, Sicher \& DuBrull, Gardner et al., Sarnat \& Laskin, Warwick \& Williams, Testut \& Latarjet, Hollinshead, Tamaki, Woodburne, D’Angelo \& Fattini, O’Rahilly, Figun \& Garino believe that the insertion of the superior head of the lateral pterygoid muscle occur in the articular capsule and in the articular disc of the TMJ.

Beyond these, other authors, such as Choukas \& Sicher, Carlson, Troiano, Porter, Honee, Gaspard et al., Landucci \& Ramalho, Frere, Bittar et al., Heylings et al., Naidoo \& Juniper, Zhang et al., Akita et al., Martins Filho \& Almeida, found similar results in their researches, it was also observed in our work. We must point out, however, that all these authors have worked with adult individuals, while in our study, only fetuses had been used.

There is, however, authors who had reached different conclusions, such as Pinkert $(1980,1984)$ who says that there is not union between the lateral pterygoid muscle and the articular disc, also affirming that there is not an insertion in the articular capsule. Such facts were not observed in our 

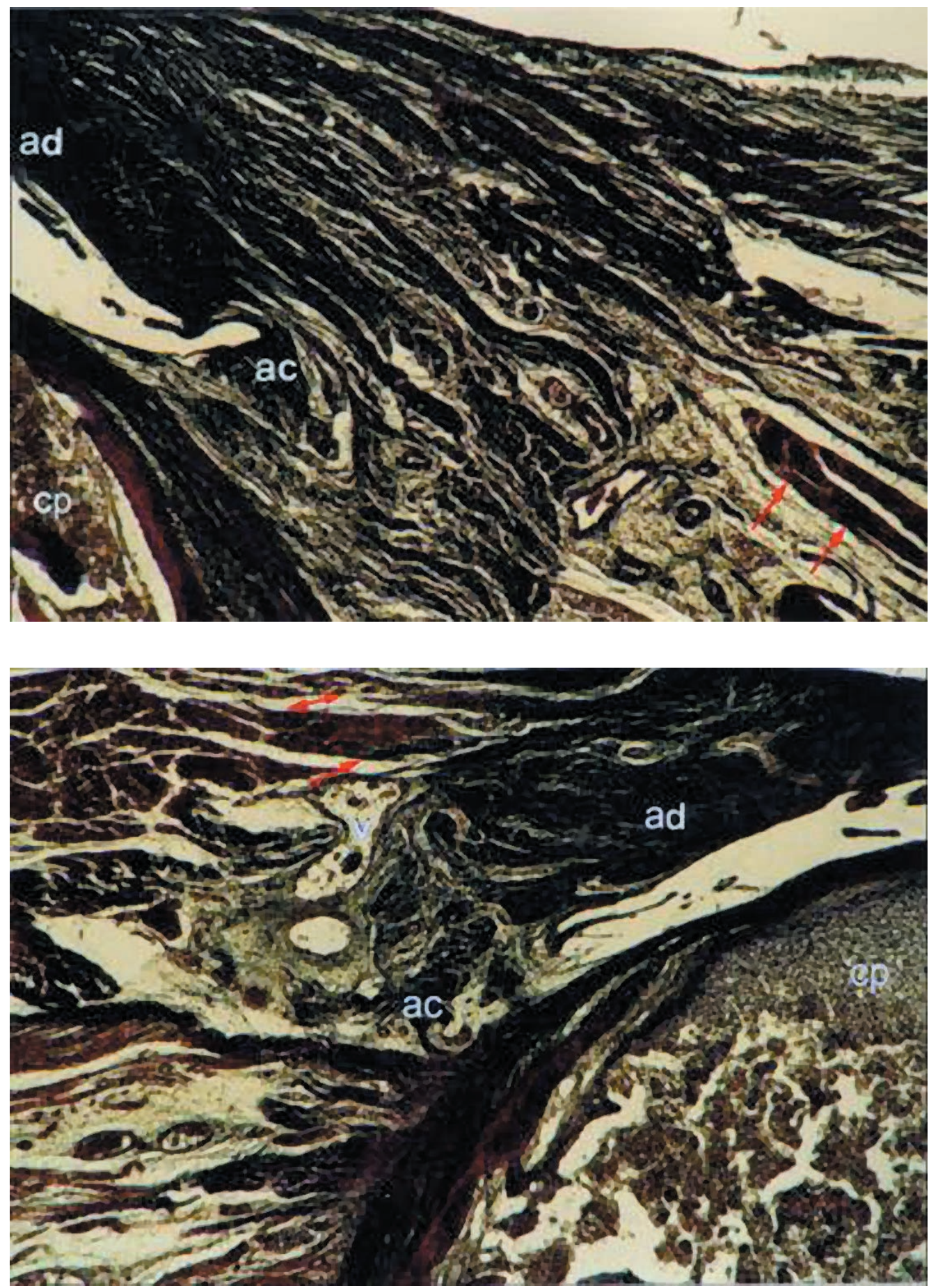

Fig. 1 - Group I (16 to 19 weeks of intrauterine life). Muscular fibers (arrows); articular capsule (ac); articular disc (ad); condylar process (cp). 40X.
Fig. 2 - Group II (20 to 23 weeks of intrauterine life). Muscular fibers inserting themselves in the articular disc (arrows); condylar process (cp); articular capsule (ac); articular disc (ad); vases (v). 40X. work, where the muscular fibers insertion of the lateral pterygoid muscle in the articular disc and in the capsule of the TMJ were verified.

Carpentier et al. that also used adult corpses, affirm that the main insertions of the superior head of the lateral pterygoid muscle are not inserted in the disc, but in the condyle, and that when this insertion occurs in the disc, the same one is only made in its medial portion. In our work we could observe that the insertion of the lateral pterygoid muscle through its superior head occurs in the articular disc, not only in its medial portion, but also in the anterior portion. According to the authors who had searched precocious aging, Symons (1952), when observing fetuses of $22 \mathrm{~mm}$ to $180 \mathrm{~mm}$, affirm that the disc becomes more evident in the ones of $70 \mathrm{~mm}$, presenting fibers insertions of the lateral pterygoid 


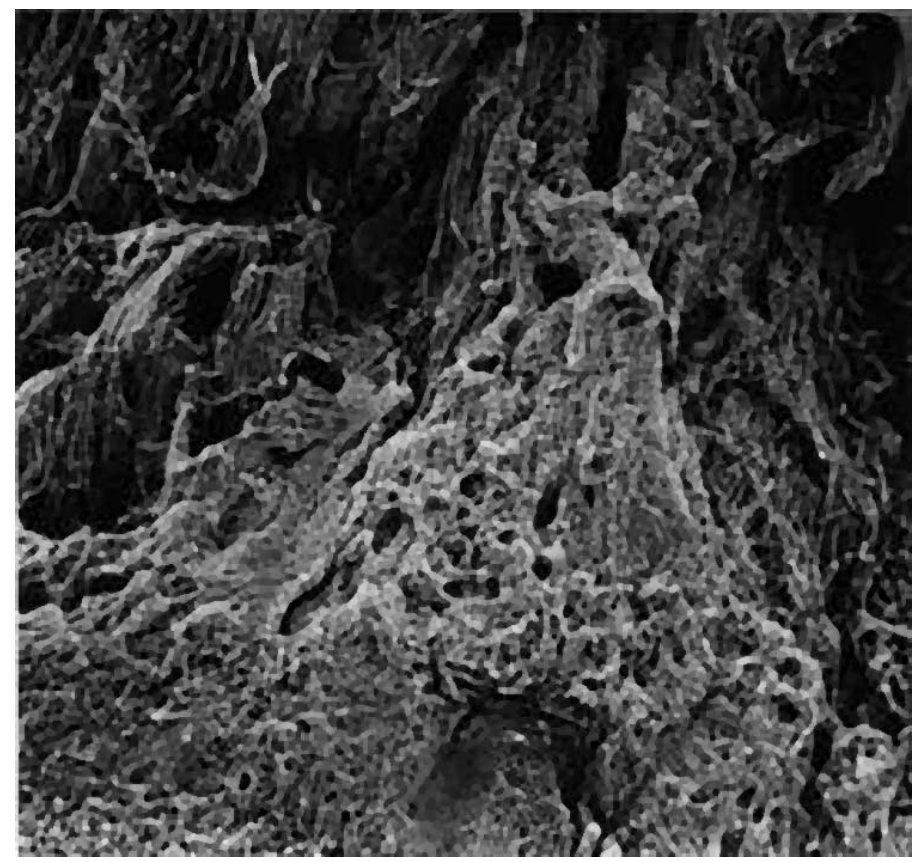

Fig. 3 - Group II (20 to 23 weeks of intrauterine life). Electronic microscopy of sweepings. Muscular fibers of the lateral pterygoid muscle inserting themselves in the articular disc. 30X.

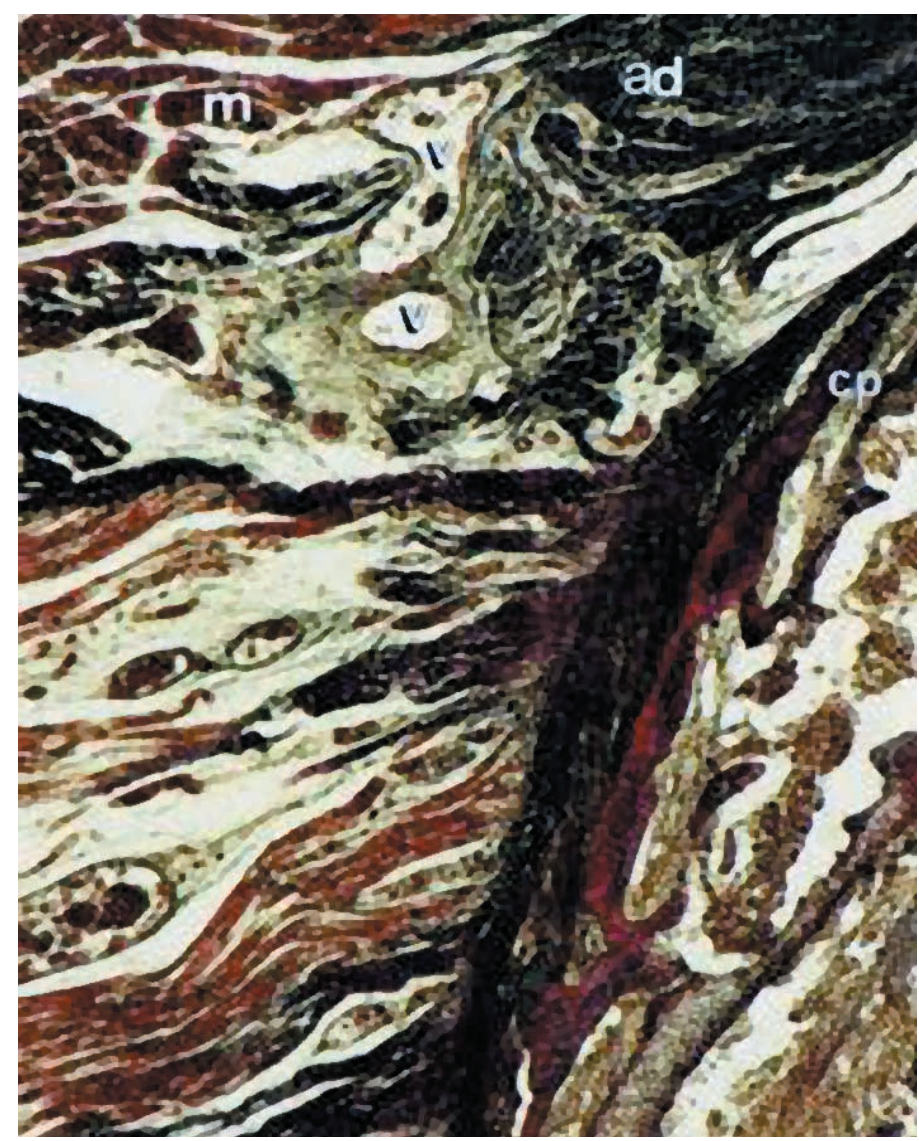

Fig. 4 - Group III (24 to 27 weeks of intrauterine life). Vases in the articular capsule (v); superior head of the lateral pterygoid muscle (m); condylar process (cp); articular disc (ad). 40X. muscle. The results obtained in our work are in accordance with the ones of Symons, once that observations done in an age range near to the one he studied, showed the articular disc well defined, with slightly sinuous fibers and insertions of the superior head of the lateral pterygoid muscle in the anterior edge.

We also agree with Baume (1962) who says that when analyzing fetuses of $65 \mathrm{~mm}$ to $85 \mathrm{~mm}$ the articular disc receives insertions from the lateral pterygoid muscle.

Wong et al. studying eight human fetuses, ranging in age from 13 weeks to 17,5 weeks observed that lateral pterygoid muscle fibers inserted into the medial aspects of the developing articular disc. We agree with this author, however, we could observe the insertion of the lateral pterygoid muscle in the anterior portion of the articular disc too. It is the same with Ogütcen-Toller \& Juniper who studied 16 human embryos and fetuses ranging in age from 5 weeks to 14 weeks founding the superior part of lateral pterygoid muscle attached to the disc superiorly and medially.

Mérida Velasco et al. relate that the superior head of the lateral pterygoid muscle seems to insert into the anteromedial two thirds of the temporomandibular joint disc, these results were similar to ours.

Minarelli \& Liberti affirm that the lateral pterygoid muscle inserts itself in an anteromedially way in the disc. They also affirm that this only occurs in fetuses and that in children, adults and old persons the main insertion occurs in the pterygoid fovea, beyond fibers inserting in the anteromedial and inferior edge of the articular capsule of the TMJ. We agree with these authors about the fetal phase, since it was not the objective of our work to study other ages.

We also agree with Wierusz \& Wozniak when relate that in fetuses of 9 and 10 weeks the articular disc is connected with the articular capsule and lateral pterygoid muscle.

Concerning the comments above, the following conclusions were obtained: the superior head of the lateral pterygoid muscle is inserted in the disc and in the articular capsule, in all the studied ages; the fibers and the thickness of the articular disc, as well as, the articular capsule, suffer modifications according to age. 

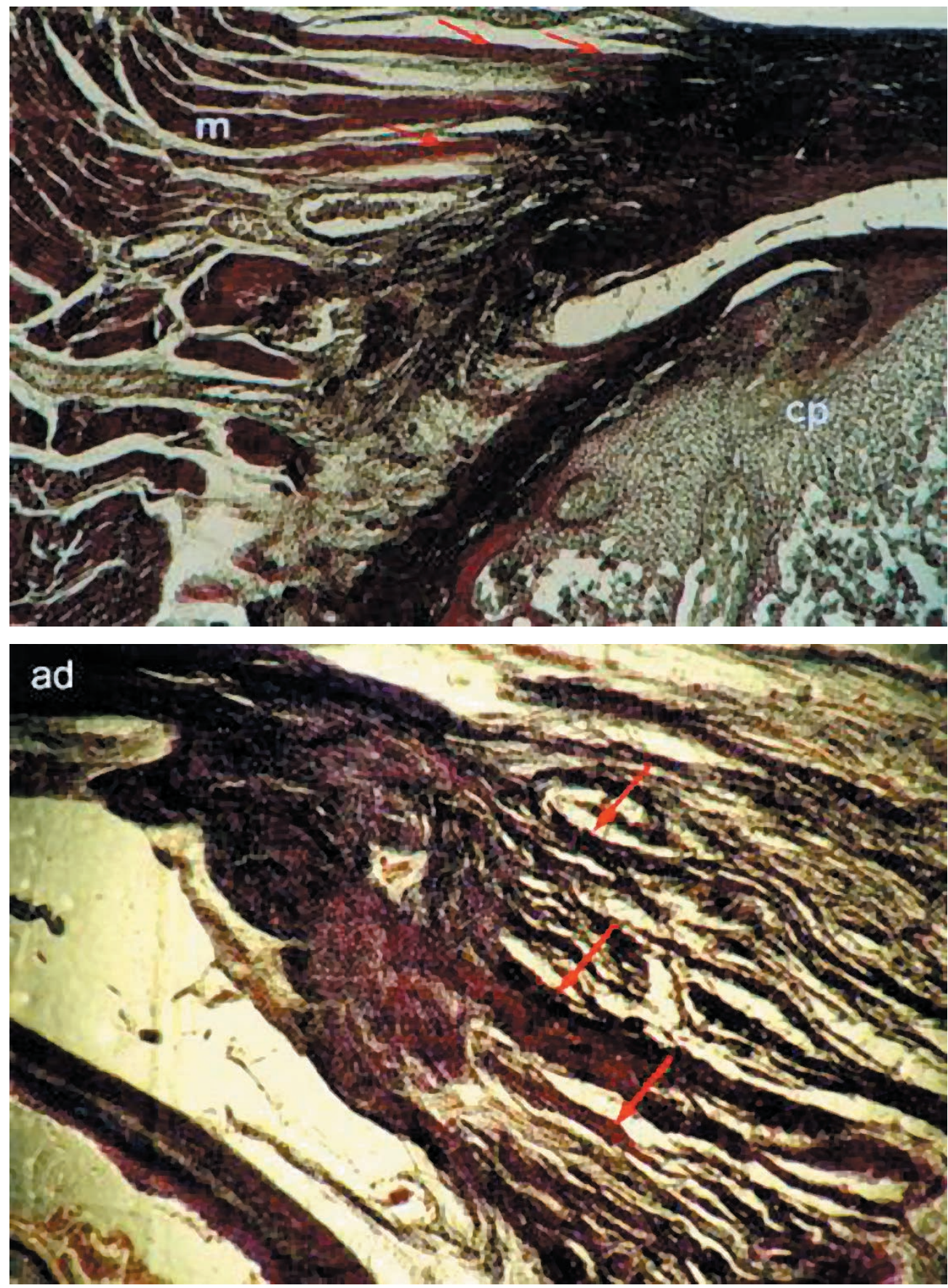

Fig. 5 - Group IV (28 to 31 and 32 to 35 weeks of intrauterine life). Insertion of the muscular fibers $(\mathrm{m})$ in the temporomandibular joint disc (arrows); condylar process (cp). $40 \mathrm{X}$.

Fig. 6 - Group V (36 to 39 weeks of intrauterine life). Fibers of the lateral pterygoid muscle (arrows) inserting themselves in the articular disc (ad). 40X.

ALTRUDA FILHO, L. \& ALVES, N. Inserción de la cabeza superior del músculo pterigoideo lateral en fetos humanos. Int. J. Morphol., 24(4):643-649, 2006.

RESUMEN: El músculo petrigoideo lateral, más específicamente su cabeza superior, como es conocida, está estrechamente relacionada con la articulación témporomandibular. Particularmente en niños, en contraste con lo observado en adultos, estas articulaciones han sido raramente estudiadas, por aspectos anatomofuncionales, escasos conocimientos de sus funciones en los períodos embrionario y fetal. Fueron utilizados 12 fetos, de 16 a 19 semanas de vida intrauterina, en los cuales fue observada que la cabeza superior del músculo petrigoideo lateral estaba insertada en el disco y en la cápsula articular, en todos los grupos estudiados. Además, fue posible observar que, tanto las fibras y el espesor del disco articular, como la cápsula articular, sufren modificaciones de acuerdo con el período de desarrollo.

PALABRAS CLAVE: Articulación temporomandibular; Músculo pterigoideo lateral; Disco articulación temporomandibular. 


\section{REFERENCES}

Akita, K.; Shimokawa, T. \& Sato, T. Positional relationships between the masticatory muscles and their innervating nerves with special reference to the lateral pterygoid and the midmedial and discotemporal muscle bundles of temporalis. J. Anat., 197(Pt2):291-302, 2000.

Baume, L. J. Ontogenesis of the human temporomandibular joint. Development of the condyles. J. Dent. Res., 41:1327-39. 1962.

Bittar, G.T.; Bibb, C.A. \& Pullinger, A.G. Histologic characteristics of the lateral pterygoid muscle insertion to the temporomandibular joint. J. Orofac. Pain, 8(3):243-9, 1994.

Carlson, H.L. Functional anatomy and dynamics of the temporomandibular joint. S. C. Dent. J., 25(3):6-12, 1967.

Carpentier, P.; Yung, J.P.; Marguelles-Bonnet, R. \&Meunissier, M. Insertions of the lateral pterygoid muscle: an anatomic study of the human temporomandibular joint. J. Oral. Maxillofac. Surg., 46(6):477-82, 1988.

Castro, S.V. Anatomia fundamental. 2. ed. Rio de Janeiro, McGraw-Hill, 1975.

Chiarugi, G. Istituzioni di anatomia dell'uomo. 4. ed. Societá Editrice Libraria, 1930.

Choukas, N.C. \& Sicher, H. The structure of the temporomandibular joint. Oral Surg. Oral Med. Oral Pathol., 13(10):1203-13, 1960.

D’Angelo, J.G. \& Fattini, C.A. Anatomia humana sistêmica e segmentar. Rio de Janeiro, Atheneu, 1985.

Figun, M. E. \& Garino, R.R. Anatomia odontológica funcional e aplicada. 4. ed. Rio de Janeiro, Guanabara Koogan, 1989.

Frere, F. The role of the external pterygoid muscle in relation to the temporomandibular joint pain-dysfunction syndrome. Rev. Belge. Med. Dent., 36(4):154-7, 1981.

Gardner, E.; Gray, D. J. \& O’Rahilly, R. Anatomia. 4. ed., Rio de Janeiro, Guanabara Koogan, 1978.

Gaspard, M.; Laison, F. \& Mailland, M. Architectural organization and texture of the pterygoid muscles in man. J. Biol. Buccale, 1(4):353-66, 1973.

Heylings, D. J.; Nielsen, I. L. \& McNeill, C. Lateral pterygoid muscle and the temporomandibular disc. $J$. Orofac. Pain, 9(1):9-16, 1995.

Hollinshead, W.P. Livro-texto de anatomia humana. 3. ed. São Paulo, Harper \& Row, 1980.

Honee, G. L. The anatomy of the lateral pterygoid muscle. Acta Morphol. Neerl. Scand., 10(4):331-40, 1972.

Landucci, C. \& Ramalho, L.R. Lateral pterygoid muscle and its insertion in the meniscus of the human temporomandibular joint. Rev. Fac. Farm. Odontol. Araraquara, 8(2):191-5, 1974.

Martins Filho, C.M. \& Almeida, S.M. Estudo histológico da inserção do músculo pterigóideo lateral na ATM humana. Rev. Assoc. Paul. Cir. Dent., 56(5):338-44, 2002.

Mérida Velasco, J. R.; Rodriguez Vazquez, J. F. \& Jimenez Collado, J. The relationships between the temporomandibular joint disc and related masticatory muscles in humans. J. Oral. Maxillof. Surg., 51(4):3905, discussion 395-6, 1993.

Minarelli, A. M. \& Liberti, E. A. Relação entre o feixe superior do músculo pterigóideo lateral e o disco da ATM humana: estudo ao microscópio de luz. Rev. Odontol. Univ. São Paulo, 10(3):175-9, 1996.

Naidoo, L. C. \& Juniper, R. P. Morphometric analysis of the insertion of the upper head of the lateral pterygoid muscle. Oral Sugr. Oral Med. Oral Pathol. Oral Radiol. Endod., 83(4):441-6, 1997.

Ogutcen-Toller, M \& Juniper, R. P. The embryologic development of the human lateral pterygoid muscle and its relationships with the temporomandibular joint disc and Meckel's cartilage. J. Oral Maxillofac. Surg., 51(7):772-8; discussion 778-9, 1993.

O’Rahilly, R. Anatomia Humana básica. Rio de Janeiro, Interamericana, 1985.

Piette, E. Anatomy of the human temporomandibular joint. An updated comprehensive review. Acta Stomatol. Belg., 90(2):103-27, 1993. 
Pinkert, R. Anatomical structure of the temporomandibular joint and the movement of its tissues during mouth opening. Stomatol. DDR., 30(10):744-50, 1980.

Pinkert, R. Relation between the lateral pterygoid muscle and the articular disk and their significance for movement in the temporo-mandibular joint. Zahn Mund Kieferheilkd Zentralbl, 72(6):553-8, 1984.

Porter, M. R. The attachment of the lateral pterygoid muscle to the meniscus. J. Prosthet. Dent., 24(5):555-62, 1970.

Sarnat, B. G. The temporomandibular joint. 2. ed. Springfield Thomas Publisher, 1964.

Sarnat, B.G. \& Laskin, D.M. The temporomandibular joint. 3. ed. Springfield Thomas Publisher, 1979.

Sicher, H. \& Du Brull, E. L. Anatomia bucal. 6. ed. Rio de Janeiro, Guanabara Koogan, 1977.

Symons, N.B. The development of the human mandibular joint. J. Anat., 86(3):326-32, 1952.

Tamaki, T. ATM - Noções de interesse protético. 3. ed. São Paulo, Sarvier, 1981.

Testut, L. \& Latarjet, A. Tratado de anatomia humana. 9. ed. Barcelona, Salvat, 1979.

Troiano, M. F. New concept of the insertion of the lateral pterygoid muscle. J. Oral Surg., 25(4):337-40, 1967.

Warwick, R. \& Willians, P. L. Anatomia. Rio de Janeiro, Guanabara Koogan, 1979.

Wierusz, A. \& Wozniak, W. Early fetal development of the articular disc in the human temporomandibular joint. Folia Morphol. (Warsz), 63(2):185-8, 2004.

Wong, G.B.; Weinberg, S.; Symington, J.M. Morphology of the developing articular disc of the human temporomandibular joint. J. Oral Maxillofac. Surg., 43(8):565-9, 1985.

Woodburne, R.T. Anatomia humana. Rio de Janeiro, Guanabara Koogan, 1984.

Zhang, L.; Sun, L.; Ma, X. A macroscopic and microscopic study of the relationship between the superior lateral pterygoid muscle and the disc of the temporomandibular joint. Zhonghua Kou Qiang Yi Xue Za Zhi, 33(5):2679, 1998.
Correspondence to: Prof. Dr. Nilton Alves

Universidade Estadual Paulista gúlio de Mesquita Filfo

Rua Humaitá, 1680

CEP $\quad 148011-903$

Campus Araraquara - Araraquara/São Paulo

BRASIL

Email: niltonnalves@hotmail.com

Received: 22-08-2006

Accepted: 29-09-2006 